\title{
SISTEM INFORMASI MONITORING KEGIATAN SANTRI BERBASIS ANDROID STUDI KASUS : PESANTREN AL-HIDAYAH GARUT
}

\author{
Muhamad Sabar ${ }^{1}$, Agus Heryanto ${ }^{2}$, Fuji Lestari ${ }^{3}$ \\ Teknik Informatika ${ }^{1,2,3}$ \\ Sekolah Tinggi Teknologi Bandung \\ Jl. Soekarno Hatta No. 378 Bandung \\ m.sabar.sttb@gmail.com ${ }^{1}$, agus.heryanto.1992@gmail.com ${ }^{2}$, fujilestari308@gmail.com ${ }^{3}$
}

\begin{abstract}
Abstrak
Anak merupakan tanggung jawab orang tua yang di berikan oleh Allah S.W.T, oleh karena itu sudah sepatutnya orang tua harus menjaga dan mengawasinya, terutama ketika orang tua memutuskan untuk memasukan anaknya ke dalam sebuah pondok pesantren. Atas dasar itu terkadang waktu serta jarak yang jauh biasanya menjadi kendala utama orang tua dalam memperoleh informasi, ditambah lagi dengan keterlambatan pihak pesantren dalam memberikan informasi kepada orang tua santri. Dengan menerapkan teknologi informasi, maka pihak pesantren dapat lebih mudah dan cepat dalam memberikan informasi kepada orang tua santri, dan orang tua santri juga dapat turut serta mengawasi anaknya dalam hal memperoleh informasi yang berkaitan dengan Kegiatan santri, absensi santri dan pelanggaran yang dilakukan oleh santri.
\end{abstract}

Hasil dari penelitian ini adalah Aplikasi Monitoring Kegiatan Santri Berbasis Android menggunakan jenis penelitian kualitatif, sedangkan metode pengumpulan datanya menggunakan observasi, wawancara, dan studi literatur. Metode pengembangannya menggunakan metode waterfall dan pengujian aplikasi menggunakan metode blackbox. Adapun kesimpulan yang diperoleh dari penelitian ini adalah aplikasi e-monitoring AlHidayah ini memudahkan orang tua dalam memperoleh informasi santri selama mondoksehingga orang tua dapat memperoleh data santri lebih detail.

Kata kunci :

Monitoring, Sistem Informasi, Aktivitas Santri, Pesantren

\begin{abstract}
Children are the responsibility of parents given by Allah S.W.T, therefore it is fitting for parents to guard and supervise them, especially when parents decide to include their children in a boarding school. On that basis sometimes time and distance are usually the main obstacles for parents in obtaining information, coupled with delays in the Islamic Boarding Schools in providing information to parents of students. By implementing information technology, the pesantren can more easily and quickly provide information to santri parents, and santri parents can also participate in supervising their children in terms of obtaining information relating to santri activities, santri absences and violations committed by Student.
\end{abstract}

The results of this study are the Android-Based Santri Activity Monitoring Application using qualitative research types, while the data collection method uses observation, interviews, and literature studies. The method of development uses the Waterfall method and application testing uses the Balck Box method. The conclusion obtained from this study is the application of Al-Hidayah E-Monitoring makes it easy for parents to obtain information of students during the school so that parents can obtain more detailed data of students

Keywords :

Monitoring, Information Systems, Student Activities, Islamic Boarding Schools 


\section{Pendahuluan}

Pada pendidikan pesantren yang mewajibkan santrinya untuk menginap di pesantren, seperti Pesantren Al-Hidayah, pihak pesantren menginginkan sebuah sistem yang dapat memberikan informasi yang berhubungan dengan kegiatan santri, absensi santri dan pelanggaran yang di lakukan oleh santri selama mondok di pesantren A-Hidayah sehingga dapat menambah kepercayaan orang tua untuk menempatkan anaknya dalam Pesantren.

Anak merupakan tanggung jawab orang tua yang di berikan oleh Allah S.W.T, oleh karena itu sudah sepatutnya orang tua harus menjaga dan mengawasinya, terutama ketika orang tua memutuskan untuk memasukan anaknya ke dalam sebuah pondok pesantren.

Atas dasar itu terkadang waktu serta jarak yang jauh biasanya menjadi kendala utama orang tua dalam memperoleh informasi, ditambah lagi pihak pesantren masih menggunakan cara manual untuk memberikan informasi kepada orang tua santri yaitu dengan menyebarkan surat kepada orang tua santri, sehingga akan menyebabkan keterlambatan pihak pesantren dalam memberikan informasi kepada orang tua santri yang berkaitan dengan kegiatan santri, absensi santri dan pelanggaran yang dilakukan oleh santri.

\section{KAJIAN LITERATUR}

Menurut (McLeod, 2004) sistem adalah sekelompok elemen elemen yang terintegrasi dengan tujuan yang sama untuk mencapai tujuan. Menurut (McLeod, 2004) informasi adalah data yang diolah menjadi bentuk lebih berguna dan lebih berarti bagi yang menerimanya. Informasi juga disebut data yang diproses atau data yang memiliki arti. Informasi merupakan data yang telah diproses sedemikian rupa sehingga meningkatkan pengetahuan seseorang yang menggunakan.

Para pembuat keputusan memahami bahwa informasi menjadi faktor kritis dalam menentukan kesuksesan atau kegagalan dalam suatu bidang usaha. Sistem apapun tanpa ada informasi tidak akan berguna, karena sistem tersebut akan mengalami kemacetan dan akhirnya berhenti. Informasi dapat berupa data mentah, data tersusun, kapasitas sebuah saluran informasi, dan sebagainya. Sistem informasi merupakan kombinasi teratur dari orang-orang, perangkat keras, perangkat lunak, jaringan komunikasi, dan sumber daya data yang mengumpulkan, mengubah, dan menyebarkan informasi dalam sebuah organisasi. [1]

\section{II.2 PHP (Hypertext Preprocessor)}

PHP atau kependekan dari Hypertext Preprocessor adalah salah satu bahasa pemrograman open source yang sangat cocok atau dikhususkan untuk pengembangan web dan dapat ditanamkan pada sebuah skripsi HTML. Bahasa PHP dapat dikatakan menggambarkan beberapa bahasa pemrograman seperti C, Java, dan Perl serta mudah untuk dipelajari. Tiga tahapan yang dilakukan sebelum PLN mencabut listrik pelanggan adalah sebagai berikut. [1]

\section{II.3 MySQL}

MySQL Merupakan basis data yang bersifat open source sehingga banyak di gunakan untuk media. Walaupun gratis, MySQL tetap berkualitas dan sudah cukup memberikan performance yang memadai.

Penggunaan PHP MyAdmin lebih mudah digunakan karena menggunakan interface yang lebih mudah dipahami.[2]

\section{II.4 Basis Data}

Menurut Sutanta, basis data dapat di pahami sebagai suatu kumpulan data terhubung (Inaterrelated data) yang disimpan secara bersama-sama pada suatu media.

Tetapi mengatap satu sama lain atau tidak perlu suatu kerangkapan data, data disimpan dengan caracara tertentu sehingga mudah digunakan atau dtampilkan kembali; data dapat digunakan oleh satu atau lebih program-program aplikasi secara optimal; data disimpan tampa mengalami ketergantungan dengan program yang akan menggunakannya; data disimpan sedemikian rupa sehingga proses penambahan, pengambilan dan modifikasi data dapat di lakukan dengan mudah dan terkontrol [3].

\section{II.5 Web Server}

Web server adalah aplikasi yang berfungsi untuk melayani permintaan pemanggilan alamat dari pengguna melalui web browser, dimana web server mengirimkan kembali informasi yang diminta tersebut melalui HTTP (HyperText Transfer Protocol) untuk ditampilkan ke layar monitor kita.[4] 


\section{II.6 OOP (Object Oriented Programming)}

OOP (Object Oriented Programming) adalah sebuah istilah yang diberikan kepada bahasa pemrograman yang menggunakan tehnik berorientasi atau berbasis pada sebuah obyek dalam pembangunan program aplikasi, maksudnya bahwa orientasi pembuatan program tidak lagi menggunakan orientasi linear melainkan berorientasi pada objek-objek yang terpisah-pisah. Suatu perintah dalam bahasa ini diwakili oleh sebuah Obyek yang didalamnya berisi beberapa perintah-perintah standar sederhana. Obyek ini dikumpulkan dalam Modul form atau report atau modul lain dan disusun didalam sebuah project

\section{ANALisis dan PERANCANGan}

\section{III.1 Metode Pengembangan Sistem}

Metode penelitian yang diterapkan pada penelitian ini adalah dengan pengembangan metode waterfall. Karena metode waterfall merupakan model pengembangan sistem informasi yang sistematik dan sekuensial.[6]

Dalam pengembangannya metode waterfall memiliki beberapa tahapan yang berurut yaitu :

\section{Requirement Analysis}

Tahap ini pengembang sistem diperlukan komunikasi yang bertujuan untuk memahami perangkat lunak yang diharapkan oleh pengguna dan batasan perangkat lunak tersebut. Informasi ini biasanya dapat diperoleh melalui wawancara, diskusi atau survei langsung. Informasi dianalisis untuk mendapatkan data yang dibutuhkan oleh pengguna.

\section{System Design}

Spesifikasi kebutuhan dari tahap sebelumnya akan dipelajari dalam fase ini dan desain sistem disiapkan. Desain sistem membantu dalam menentukan perangkat keras dan sistem persyaratan dan juga membantu dalam mendefinisikan arsitektur sistem secara keseluruhan.

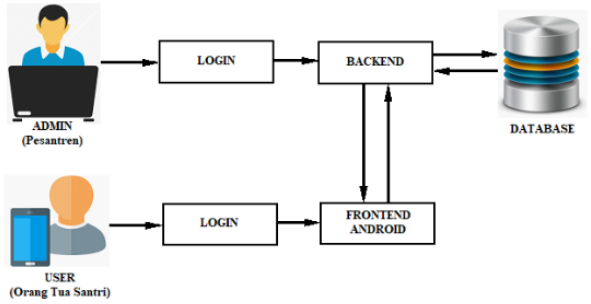

Gambar 3.1 Gambaran umum sistem

Use case merupakan gambaran skenario dari interaksi antara pengguna dengan sistem. Sebuah diagram use case menggambarkan hubungan antara user dan kegiatan yang dapat dilakukan terhadap aplikasi. Dan pada sistem ini terdapat 2 aktor yaitu admin Pesantren, dan orang tua santri.

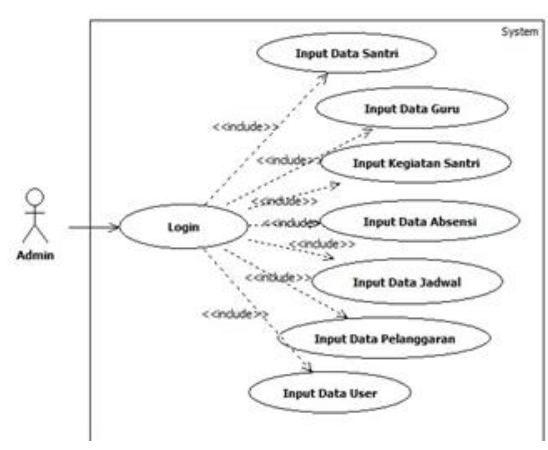

Gambar 3.2 Use Case Diagram Admin

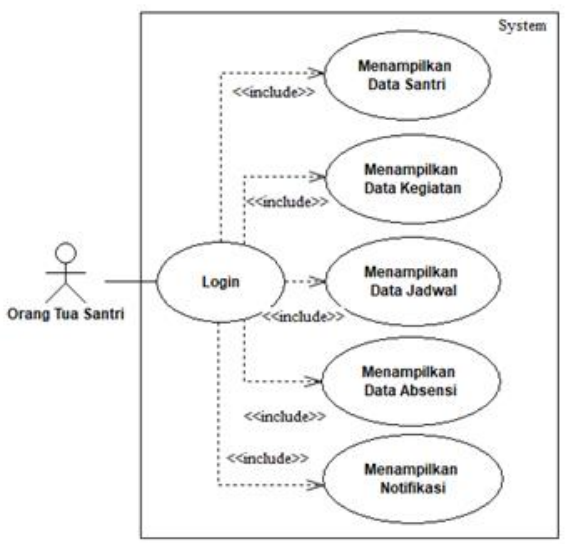

Gambar 3.3 Use Case Diagram User 


\section{Implementation}

Pada tahap ini, sistem pertama kali dikembangkan di program kecil yang disebut unit, yang terintegrasi dalam tahap selanjutnya. Setiap unit dikembangkan dan diuji untuk fungsionalitas yang disebut sebagai unit testing.

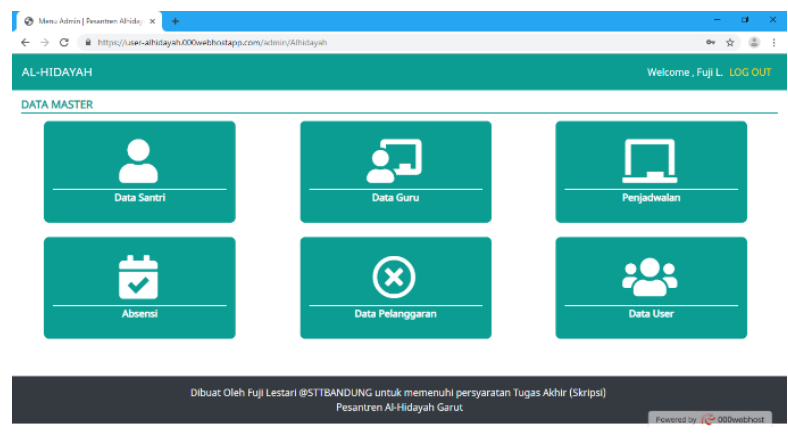

Gambar 4.2 Halaman Utama

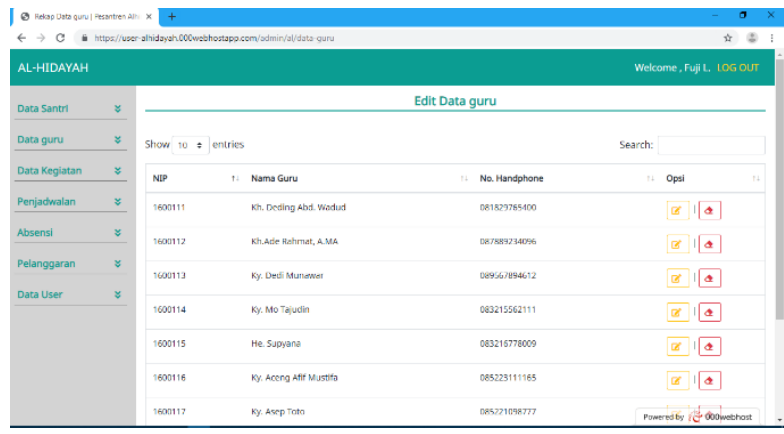

Gambar 4.3 Halaman Data Santri

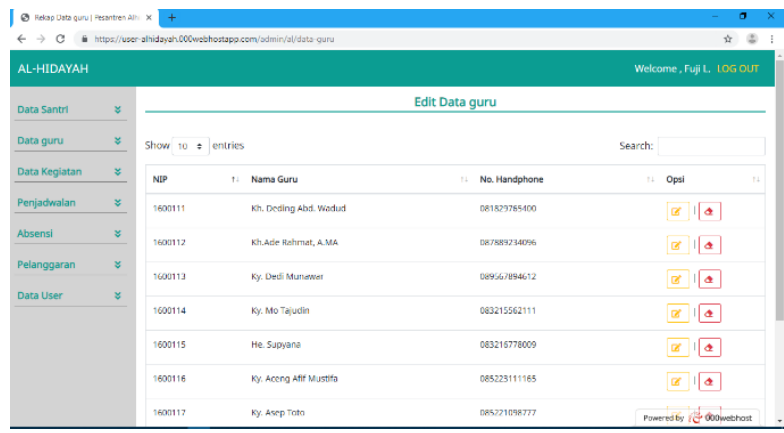

Gambar 4.4 Halaman Data Guru

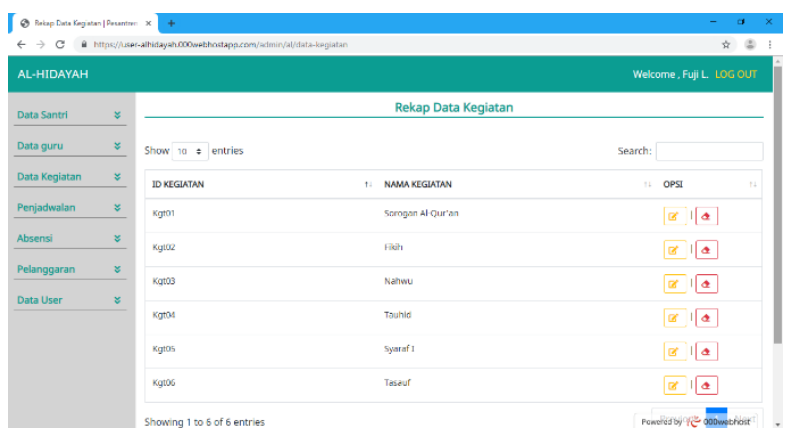

Gambar 4.5 Halaman Data Kegiatan

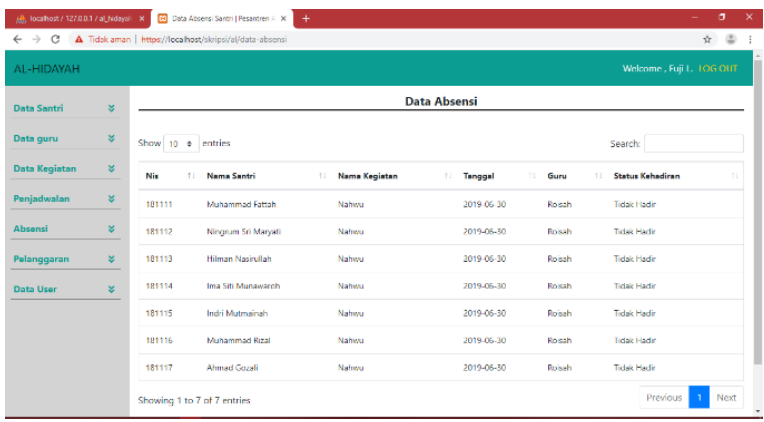

Gambar 4.6 Halaman Absensi

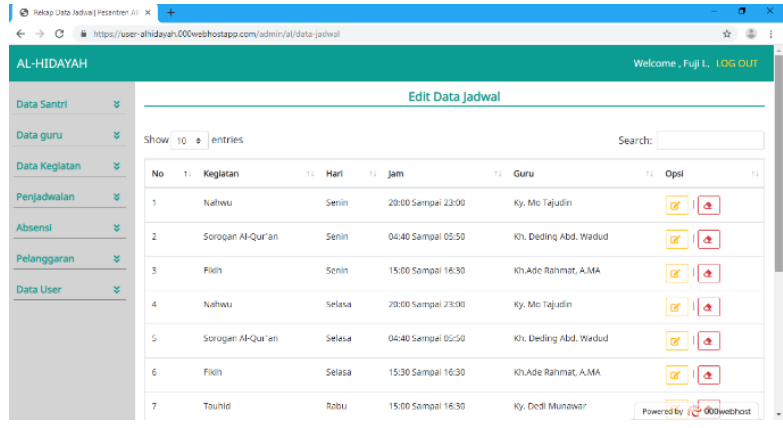

Gambar 4.7 Halaman Penjadwalan 


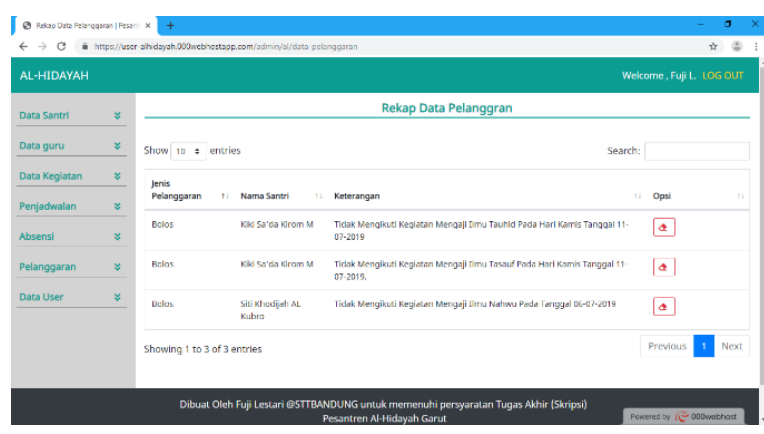

Gambar 4.8 Halaman Pelanggaran

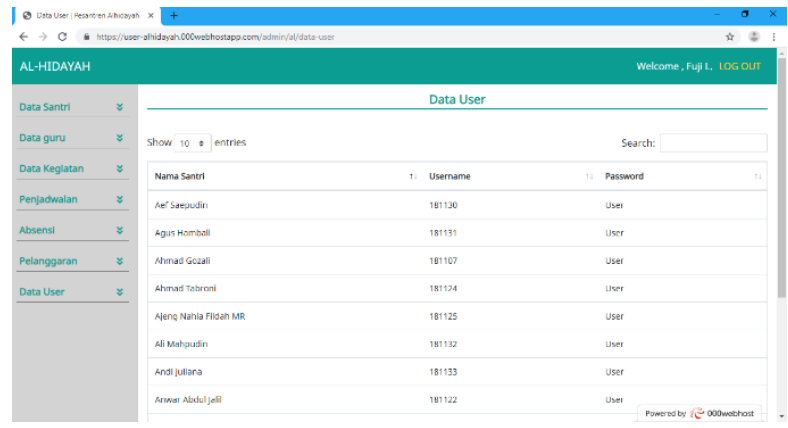

Gambar 4.8 Halaman Data User

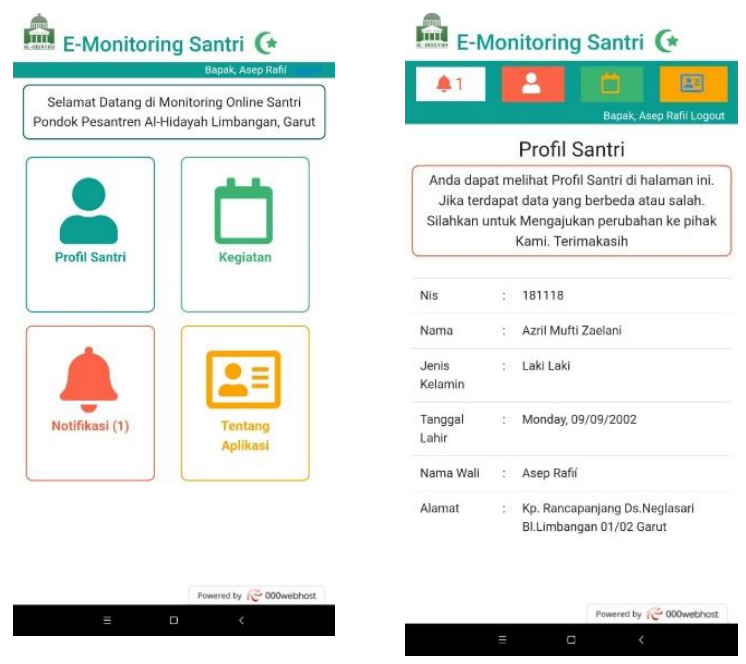

Gambar 4.9 Halaman Utama \& Data siswa

\section{Integration \& Testing}

Seluruh unit yang dikembangkan dalam tahap implementasi diintegrasikan ke dalam sistem setelah pengujian yang dilakukan masing-masing unit. Setelah integrasi seluruh sistem diuji untuk mengecek setiap kegagalan maupun kesalahan.

\section{Operation \& Maintenance}

Tahap akhir dalam model waterfall. Perangkat lunak yang sudah jadi, dijalankan serta dilakukan pemeliharaan. Pemeliharaan termasuk dalam memperbaiki kesalahan yang tidak ditemukan pada langkah sebelumnya. Perbaikan implementasi unit sistem dan peningkatan jasa sistem sebagai kebutuhan baru.

\section{KESIMPULAN DAN SARAN}

\section{IV.1 Kesimpulan}

Berdasarkan hasil penelitian yang telah dilakukan, maka kesimpulan bahwa informasi yang diberikan telah membantu orang tua santri dalam memonitoring kegiatan anaknya selama di Pesantren. Serta membantu pesantren Al-Hidayah dalam memberikan kemudahan pencatatan dan penyampaian informasi.

\section{IV.2 Saran}

Untuk Pengembang sistem yang akan mengembangkan penelitian ini adalah membuat aplikasi yang lebih user friendly, menambah feature chat, berita dan prestasi santri.

\section{REFERENSI}

E-journal Teknik Elektro dan Komputer vol.5 no.2 Januari-Maret 2016, ISSN 2301-8402

Petrus F.S., Ichsan R.P., Hafni S.S . Website development fundamental : fitur, layout dan operasional lebih maju. Cet.I . Bandung : Nuansa Cendekia, 2013 : 92.

Sutanta, Edhy. 2011. Basis Data dalam Tinjauan Konseptual. Yogyakarta: Penerbit ANDI

Anhar. 2010. Panduan Menguasai PHP \& MySQL Secara Otodidak. Jakarta: Mediakita.

Muhammad Danuri. Object Oriented Programming (Oop) Pembangun Program Aplikasi Berbasis Windows. 2009; 42. 
Presman, R.S. 2002. Rekayasa Perangkat Lunak: Pendekatan Praktisi (Buku Dua). Yogyakarta : Penerbit Andi. 